\title{
Stabilization of Enzymes by Multipoint Covalent Attachment on Aldehyde-Supports: 2-Picoline Borane as an Alternative Reducing Agent
}

\author{
Alejandro H. Orrego ${ }^{1}$ (D), Maria Romero-Fernández ${ }^{1}$, María del Carmen Millán-Linares ${ }^{2}$ (D), \\ María del Mar Yust ${ }^{2}$, José M. Guisán ${ }^{1, *(\mathbb{D})}$ and Javier Rocha-Martin ${ }^{1, * \text { (D) }}$ \\ 1 Department of Biocatalysis, Institute of Catalysis and Petrochemistry (ICP) CSIC, Campus UAM, \\ Cantoblanco, 28049 Madrid, Spain; a.herrera@csic.es (A.H.O.); maria.romero@csic.es (M.R.-F.) \\ 2 Group of Plant Proteins, Instituto de la Grasa CSIC, Carretera Utrera Km 1, 41012 Seville, Spain; \\ mcmillan@ig.csic.es (M.d.C.M.-L.); mdmar@cica.es (M.d.M.Y.) \\ * Correspondence: jmguisan@icp.csic.es (J.M.G.); javirocha@icp.csic.es (J.R.-M.); \\ Tel.: +34-91-585-4809 (J.M.G. \& J.R.-M.)
}

Received: 26 July 2018; Accepted: 11 August 2018; Published: 15 August 2018

\begin{abstract}
Enzyme immobilization by multipoint covalent attachment on supports activated with aliphatic aldehyde groups (e.g., glyoxyl agarose) has proven to be an excellent immobilization technique for enzyme stabilization. Borohydride reduction of immobilized enzymes is necessary to convert enzyme-support linkages into stable secondary amino groups and to convert the remaining aldehyde groups on the support into hydroxy groups. However, the use of borohydride can adversely affect the structure-activity of some immobilized enzymes. For this reason, 2-picoline borane is proposed here as an alternative milder reducing agent, especially, for those enzymes sensitive to borohydride reduction. The immobilization-stabilization parameters of five enzymes from different sources and nature (from monomeric to multimeric enzymes) were compared with those obtained by conventional methodology. The most interesting results were obtained for bacterial $(R)$-mandelate dehydrogenase (ManDH). Immobilized ManDH reduced with borohydride almost completely lost its catalytic activity (1.5\% of expressed activity). In contrast, using 2-picoline borane and blocking the remaining aldehyde groups on the support with glycine allowed for a conjugate with a significant activity of $19.5 \%$. This improved biocatalyst was 357 -fold more stable than the soluble enzyme at $50{ }^{\circ} \mathrm{C}$ and $\mathrm{pH}$. The results show that this alternative methodology can lead to more stable and active biocatalysts.
\end{abstract}

Keywords: enzyme immobilization; 2-picoline borane; biocatalysis; glyoxyl agarose; Schiff base; enzyme stabilization

\section{Introduction}

The use of enzymes in industrial processes has been gaining interest in recent decades [1-3]. These biocatalysts allow chemical reactions to be performed under milder conditions and without side reactions [4]. In most cases, the improvement of enzyme properties is necessary, especially stability, because the reaction conditions in the industry are more challenging than in nature [4,5]. Scientists have made enormous efforts to develop methods to increase the stability of proteins. These approaches range from molecular biology [5] to physico-chemical [6,7] strategies.

Protein immobilization is a physicochemical strategy that has proven to be a simple and cost-efficient methodology to generate improved biocatalysts $[7,8]$. The immobilized proteins are usually more stable than the soluble enzyme [9]. Moreover, a well-designed immobilization strategy 
could alter the selectivity or specificity of the enzymes [10], and could even remove the substrate or product inhibitory effects [11]. In addition, enzyme immobilization allows for the recycling of catalysts and it simplifies the downstream processing, which is another critical requirement for the industry $[2,8,12]$.

Different methods for enzyme immobilization have been described in the scientific literature in recent years, e.g., encapsulation, entrapment, cross-linking enzyme aggregates or crystals, adsorption and covalent attachment $[8,13-16]$. Among the covalent methods, one of the most effective approaches are enzyme immobilization by multipoint covalent attachment on supports functionalized with glyoxyl (short aliphatic aldehydes) groups [8,9]. This attachment consists of the irreversible immobilization of proteins to an insoluble support such as silica [17], agarose [18], or methacrylic polymers [19,20], magnetic nanoparticles [21], even lignocellulosic wastes [22,23]. One of these supports is cross-linked agarose, which consists of macroporous agarose beads functionalized with glyoxyl groups (GA). This immobilization chemistry promotes a very intense multipoint covalent attachment through Schiff base formation between the aldehydes of the support surface and the non-protonated amino groups of the enzyme surface $[9,18]$. Moreover, this immobilization protocol can be applied to commercial polyacrylic supports (e.g., Sepabeads and Purolite) containing epoxy groups [20]. Usually, these supports also contain glyceryl groups that derive from the epoxide groups. At this point, supports containing glyceryl (easily oxidizable with sodium periodate to glyoxyl groups) and epoxide (readily functionalized to groups that are capable of adsorbing proteins by different mechanisms) groups can be used for the synthesis of glyoxyl heterofunctional supports [24]. Moreover, all of the epoxide groups of these supports can be hydrolyzed to glyceryl groups that together with the starting glyceryl groups of the support, can be subsequently oxidized to glyoxyl groups that are able to promote an intense multipoint covalent attachment between the protein and the support.

This immobilization strategy offers important stabilization effects, due to the short spacer arms that lead to the rigidification of the enzyme structure [25]. Thus, more than 100 industrial enzymes have been highly stabilized by this immobilization protocol [8,26-28]. Figure 1 shows the standard protocol for protein immobilization on glyoxyl-activated supports. This method consists of the incubation of the enzyme at $\mathrm{pH} 10$ with the support. Under this condition, most of the lysine residues are non-protonated to promote the Schiff base formation between the enzyme and the support. Finally, a reduction step with sodium borohydride is necessary to convert the formed Schiff base into secondary amino bonds, and the unreacted aldehyde groups into inert hydroxyl groups [18]. Moreover, the immobilization conditions (such as temperature, immobilization time or activation degree of the support) have to be studied for each enzyme to optimize the stability and recovered activity after the immobilization process. Within these examples, it is possible to find enzymes from different sources (eukaryotic, prokaryotic, thermophilic, mesophilic enzymes, etc.) and structures (monomeric or multimeric enzymes, cofactor-dependent or cofactor-independent enzymes, etc.) [9,28-32].
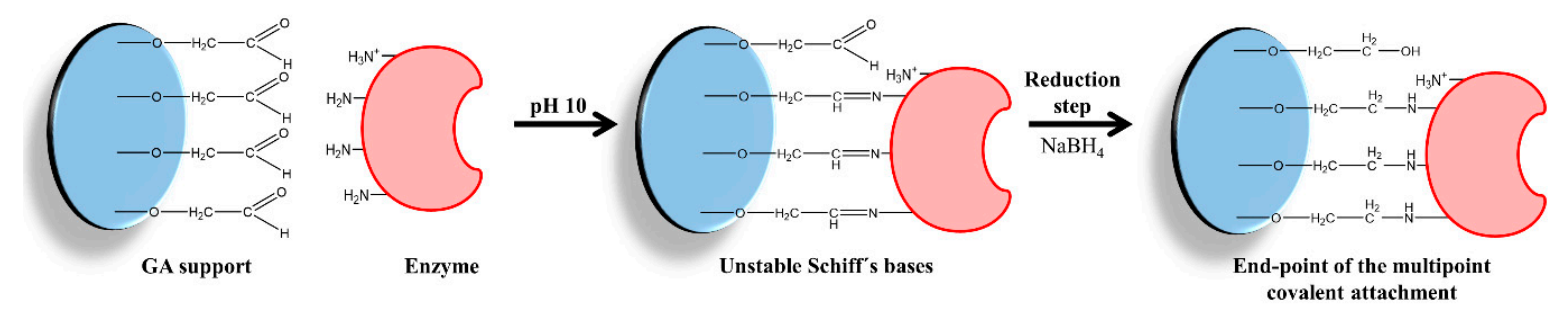

Figure 1. Schematic representation of the protein immobilization on activated glyoxyl supports. 
However, one of the main disadvantages of using this immobilization methodology is the reduction step with sodium borohydride $\left(\mathrm{NaBH}_{4}\right)$ that may adversely affect the enzyme activity. This fact is caused by the low selectivity of the borohydride to reduce the Schiff base, as well as aldehydes and ketones [33]. Nevertheless, this lack of selectivity allows for the reduction of the Schiff base and the remaining aldehydes in the support after immobilization. A known alternative to borohydride for the selective imine reduction is the use of sodium cyanoborohydride $\left(\mathrm{NaBH}_{3} \mathrm{CN}\right)$, which is commonly used for the reductive aminations [34]. It is a milder reductive agent and is much more selective than sodium borohydride. However, it presents a critical disadvantage: it possesses high toxicity and volatility $[35,36]$.

In this paper, we propose the use of 2-picoline borane (2-PB) as an alternative reducing agent for protein immobilization into aldehyde-activated supports, using GA as a model support. 2-PB is a selective and non-toxic reducing agent that is increasingly used in green chemistry for reductive amination processes [33-35]. Other authors have recently published a successful PEGylation of the human interleukin (IL)-10 using 2-PB [36], demonstrating the compatibility between this reducing agent and proteins. Herein, we present an alternative methodology, especially for enzymes that are sensitive to $\mathrm{NaBH}_{4}$ that lose their catalytic activity after the reduction step during the end-point of the multipoint covalent immobilization on glyoxyl-activated supports. However, the implementation of the 2-PB as a reducing agent presents some problems to be solved:

- The poor solubility of 2-PB in aqueous solutions.

- The necessity for obtaining an inert support after the immobilization process, reducing the remaining aldehydes to hydroxyls, or blocking them with other substances.

- The ability of the 2-PB to reduce all the Schiff bases that are formed between the enzyme and the support. 2-PB molecules, which are much larger molecules than the hydrides, have to go through the region that lies between the enzyme and the support to reduce all the Schiff base (the width of this region is approximately $2 \mathrm{~nm}$ ) [25].

To establish an alternative reduction step with 2-PB, the immobilization-stabilization parameters of six enzymes from different sources were compared with those that were obtained by the conventional methodology (using borohydride as a reducing agent). These enzymes ranged from monomeric to multimeric nature to demonstrate the general applicability of the process. Thus, the conventional immobilization on GA of five of the enzymes used in this study have been previously published: a xylanase from Streptomyces halstedii [37] (Xys1 $\Delta$ ), D-amino acid oxidase from Trigonopsis variabilis [38] (DAAO), penicillin G acylase from Escherichia coli [39] (PGA), and two dehydrogenases [11,29] (a glycerol dehydrogenase from Celullomonas sp., GlyDH, and an alcohol dehydrogenase from Thermus thermophilus HB27, ADH2). These supported biocatalysts have been used for the production of different value-added products, such as xylooligosaccharides for the Xys1 $\Delta$ biocatalyst $[20,40]$, keto-esters from D-amino acids, or 7-aminocephalosporanic acid from cephalosporin $C$ for the DAAO biocatalyst $[38,39]$ and the production of cephalosporins for the PGA biocatalyst in the pharmaceutical industry [39]. Finally, GlyDH oxidizes glycerol to 1,3-dihydroxyacetone [11], and ADH2 is a catalyst with anti-Prelog selectivity for prochiral aryl ketones, and that preferentially produces R-profens [29]. Moreover, both methodologies were applied for the immobilization-stabilization of a commercial bacterial (R)-mandelate dehydrogenase (ManDH, AppliChem, St. Louis, MO, USA) on GA. ManDH catalyzes the asymmetric reduction of aliphatic or aromatic $\alpha$-keto acids into $(R)-\alpha$-hydroxy acids. These are a group of molecules, focusing on the importance on the cosmetic, polymer, and pharmaceutical industry [41-43]. 


\section{Results}

\subsection{Immobilization of PGA, DAAO, ADH2, GlyDH, and Xys1 $\mathrm{D}$ on Glyoxyl-Activated Agarose}

GA 10BCL (10\% beads cross-linked glyoxyl-agarose) and 6BCL (6\% beads cross-linked glyoxyl-agarose) supports were highly activated with 285 and $142 \mu$ moles of aldehyde groups per gram of support, respectively. PGA (dimer), DAAO (dimer), ADH2 (dimer), GlyDH (octamer), and Xys1 $\Delta$ (monomer) were efficiently immobilized onto a GA support. As shown in Table 1, immobilization yields ranged from 75 to 100\%, and they expressed activity ranged from 25 to 65\%. Moreover, a high variability of expressed activities was observed depending on the nature of the enzyme.

The next step in the immobilization procedure was the reduction of the reversible Schiff base that was formed between the amino groups of the lysine residues on the enzyme surface, and the aldehyde groups of the support (Figure 1). Thus, the Schiff base was converted into secondary amino bonds and the remaining aldehyde groups into hydroxyl groups. All of the immobilized enzymes were reduced with $\mathrm{NaBH}_{4}$ and 2-PB to compare their expressed activities and thermal stability.

\subsection{Reduction of the Immobilized Enzymes with 2-Picoline Borane}

Recent studies on the use of 2-PB on reductive amination reactions for the analytical methods [34,35], organic synthesis [33,44], and protein modification [36], provided an excellent state-of-the-art to develop its new applications. 2-PB is commonly used in organic media [45], or heterogeneous media with a low percentage of water [46]. There are also some examples with a high percentage of water $[33,36]$. In solvent-free conditions, the maximum concentration of 2-PB dissolved in water was around $20 \mathrm{mM}$. Thus, the use of a co-solvent was needed to increase the solubility of 2-PB in aqueous media. Accordingly, when proteins are used together with 2-PB, the co-solvent that is used should be harmless for them. Another important feature is that under the reduction conditions used, the catalytic activity of the enzymes should be preserved as much as possible. In this study, we used $20 \%$ of dimethyl sulfoxide (DMSO) in aqueous buffers to dissolve up to $40 \mathrm{mM} 2-\mathrm{PB}$. All enzymes remain fully active under this selected reduction condition. The reductive amination that is performed by 2-PB is equimolar [33], and therefore, the minimum amount of 2-PB that is required to fully reduce one gram of GA, e.g., 10BCL, is approximately $300 \mu$ moles.

On the other hand, the reduction step performed with 2-PB requires a blocking agent that contains a primary amino group, since 2-PB cannot reduce free aldehyde groups into hydroxyl groups. In contrast, $\mathrm{NaBH}_{4}$ can convert the remaining aldehyde groups of the support into inert hydroxyl groups. Moreover, the Schiff base formation between the blocking agent and the support are favored when the blocking agent is in a larger excess and the $\mathrm{pH}$ is quite alkaline. In this way, three blocking agents were evaluated: ethanolamine, glycine, and Tris- $\mathrm{HCl}$.

The presence or absence of the remaining aldehyde groups was qualitatively assayed with Schiff's reagent. Figure 2 shows the presence or absence of aldehydes after the incubation of GA 10BCL support with different blocking agents, and with or without 2-PB. In the light of these results, it was possible to discard the Tris-HCl buffer as a blocking agent, since the number of aldehydes groups that were presented on the support was still high in the support, after $18 \mathrm{~h}$ of blocking (Figure 2e, intense purple color) compared to the non-reduced GA support (Figure 2b). Also, the GA support that was incubated with glycine and 2-PB led to complete blocking of the aldehydes (Figure $2 \mathrm{~g}$, white color). The incubation with ethanolamine led to an almost complete blocking of the aldehydes in the support (Figure 2i, soft purple color). Therefore, glycine and ethanolamine were studied as possible blocking agents in the enzyme immobilization experiments. 


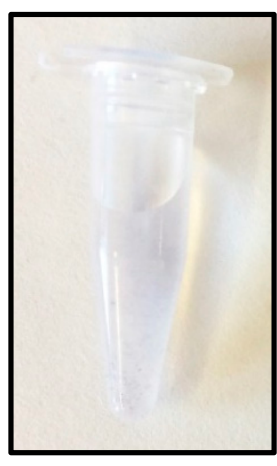

(a)

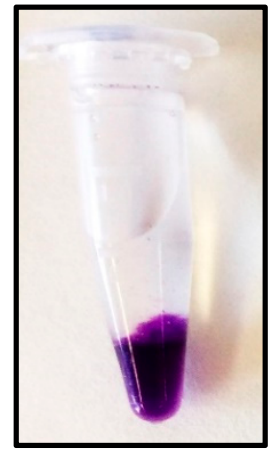

(d)

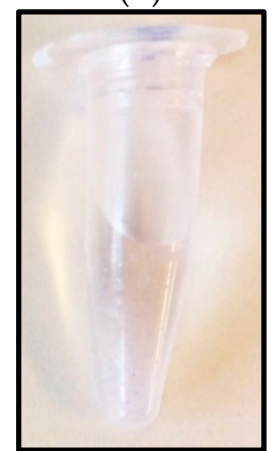

(g)

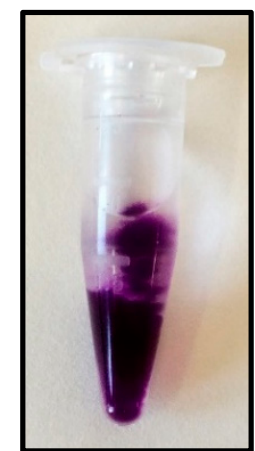

(b)

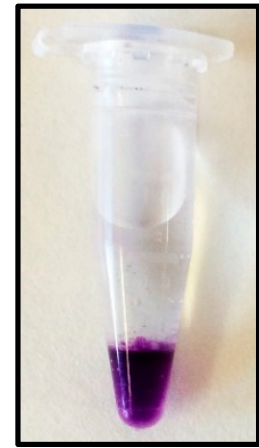

(e)

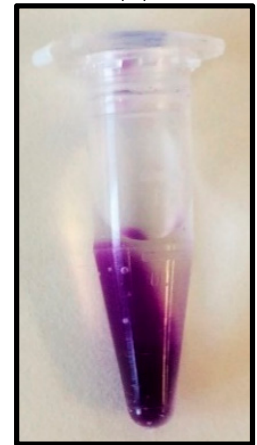

(h)

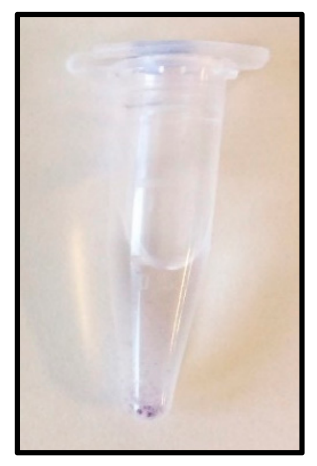

(c)

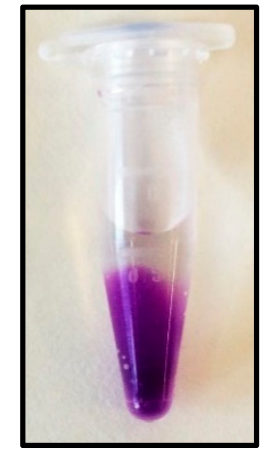

(f)

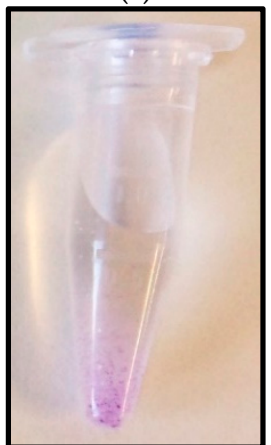

(i)

Figure 2. Detection of the free aldehydes by Schiff's reagent assay. A purple color indicates the presence of free aldehydes and a white color indicates the absence of aldehydes. All of the pictures were taken after $30 \mathrm{~min}$ of incubation with Schiff's reagent at $25^{\circ} \mathrm{C}$. All the blocking incubations were done for $18 \mathrm{~h}$ at $25^{\circ} \mathrm{C}$ using Agarose GA 10BCL in all cases: (a) Non-activated agarose beads; (b) Non-reduced GA support; (c) GA support reduced with $\mathrm{NaBH}_{4}$; (d) GA support incubated with buffer $0.8 \mathrm{M}$ Tris $\mathrm{pH} 9$ plus 20\% DMSO in the absence of 2-PB; (e) GA support incubated with buffer $0.8 \mathrm{M}$ Tris $\mathrm{pH} 9$, plus 20\% DMSO in the presence of $40 \mathrm{mM} 2-\mathrm{PB}$; (f) GA support incubated with buffer $0.8 \mathrm{M}$ glycine $\mathrm{pH}$ 9, plus 20\% DMSO in the absence of $40 \mathrm{mM}$ 2-PB; (g) GA support incubated with buffer $0.8 \mathrm{M}$ glycine $\mathrm{pH}$, plus 20\% DMSO in the presence of $40 \mathrm{mM}$ 2-PB; (h) GA support incubated with buffer $0.8 \mathrm{M}$ ethanolamine $\mathrm{pH}$ 9, plus 20\% DMSO in the absence of $40 \mathrm{mM} 2-\mathrm{PB}$; (i) GA support incubated with buffer $0.8 \mathrm{M}$ ethanolamine $\mathrm{pH} 9$, plus 20\% DMSO in the presence of $40 \mathrm{mM} 2-\mathrm{PB}$.

\subsection{Comparison of Immobilized Enzymes Reduced with Borohydride and 2-Picoline Borane: Expressed Activity} and Thermal Stability

The immobilization protocol using 2-PB as a reducing agent was tested and compared against the standard protocol of the reduction with borohydride. Thus, immobilization parameters and the thermal-stability of several proteins (PGA, DAAO, ADH2, GlyDH, and Xys1 $\Delta$ ) were determined. These proteins from different sources ranged from monomer (Xys1 $\Delta$ ) to octamer (GlyDH). Three 
different conjugates were prepared for each enzyme: reduced with borohydride (GA-B), reduced with 2-PB in the presence of glycine (GA-G), and reduced with 2-PB in the presence of ethanolamine (GA-E). In this way, it can also create different microenvironments on the support surface (e.g., ionized amino groups, glycine layers, etc.) that could have different effects on the biocatalyst properties.

Expressed activities of immobilized PGA, GlyDH, ADH2, and Xys1 $\Delta$ were not negatively affected by the reduction with borohydride, which implies the preservation of activity in the reduction step (Table 1). In contrast, the expressed activity of the immobilized DAOO was reduced by $17 \%$ after reduction with borohydride. Conjugates reduced with 2-PB presented similar or higher expressed activities than the ones reduced with borohydride, except for the immobilized GlyDH and Xys1 $\Delta$ blocked with glycine. Expressed activities of the conjugates that were reduced with 2-PB in the presence of ethanolamine were higher than the other expressed activities that were obtained by conjugates blocked with glycine, or that were reduced with borohydride. For example, immobilized GlyDH and $\mathrm{ADH} 2$ reduced with 2-PB in the presence of ethanolamine increased their activity by approximately $50 \%$ compared to the expressed activity of the conjugates after reduction with borohydride (Figure 3 ).

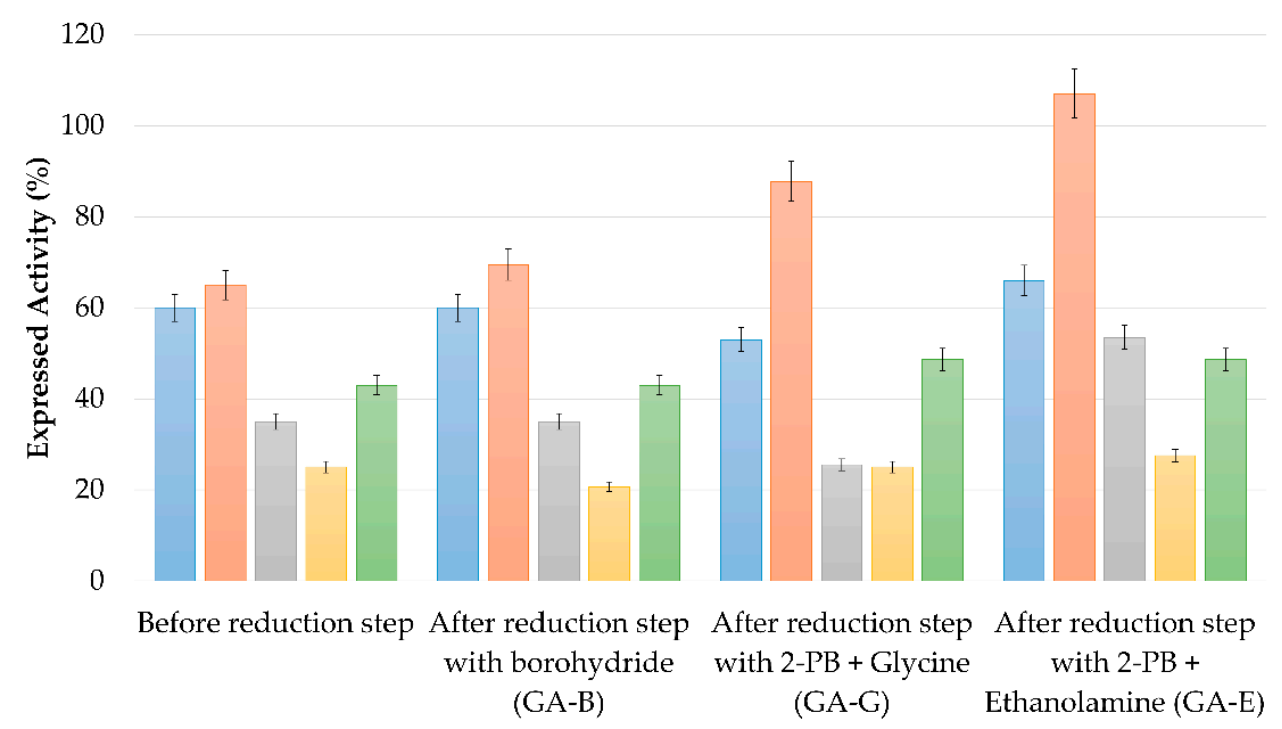

Figure 3. Expressed activities of the different conjugates before and after the reduction step. Expressed activity before reduction step $(\%)=$ (activity in the immobilized preparation before reduction)/(activity of the solution offered for immobilization - activity in the supernatant at the end of the immobilization process $) \times 100$. Expressed activity after the reduction step $(\%)=$ (activity in the immobilized preparation after reduction)/(activity of the solution that is offered for immobilization - activity in the supernatant at the end of the immobilization process) $\times 100$. Color code: $(\square)$ Xys1 $\Delta$; $\square)$ ADH2; $(\square)$ GlyDH; $(\square)$ DAAO; ( $\square$ PGA. All of the data are the mean value of three separated experiments where the error value was never higher to $5 \%$.

On the other hand, the thermal stability of the immobilized PGA and the DAAO that was reduced with borohydride was higher than that which was obtained using 2-PB as the reducing agent (Table 1 and Figure S1). Meanwhile, for GlyDH and Xys1 $\Delta$, conjugates that were reduced with borohydride or 2-PB in the presence of glycine, presented similar thermal stabilities. In contrast, immobilized ADH2 that was reduced with 2-PB and that was blocked with glycine, presented higher thermal stability than ADH2-GA-B. The half-life times of immobilized PGA, DAAO, and GlyDH that were reduced with 2-PB and that were blocked with ethanolamine were between 70- and 10-fold lower than the ones obtained by their reduced counterparts with borohydride. Conversely, ADH2 reduced with 2-PB in the presence of ethanolamine or glycine was 4- and 4.4-fold more stable than ADH2-GA-B, respectively (Table 1 and Figure S1e). These results, along with the inability of ethanolamine to block 
all remaining aldehydes groups, led us to focus on studying the use of glycine as a blocking agent during the reduction with 2-PB.

Table 1. Summary of the protein immobilization-stabilization parameters.

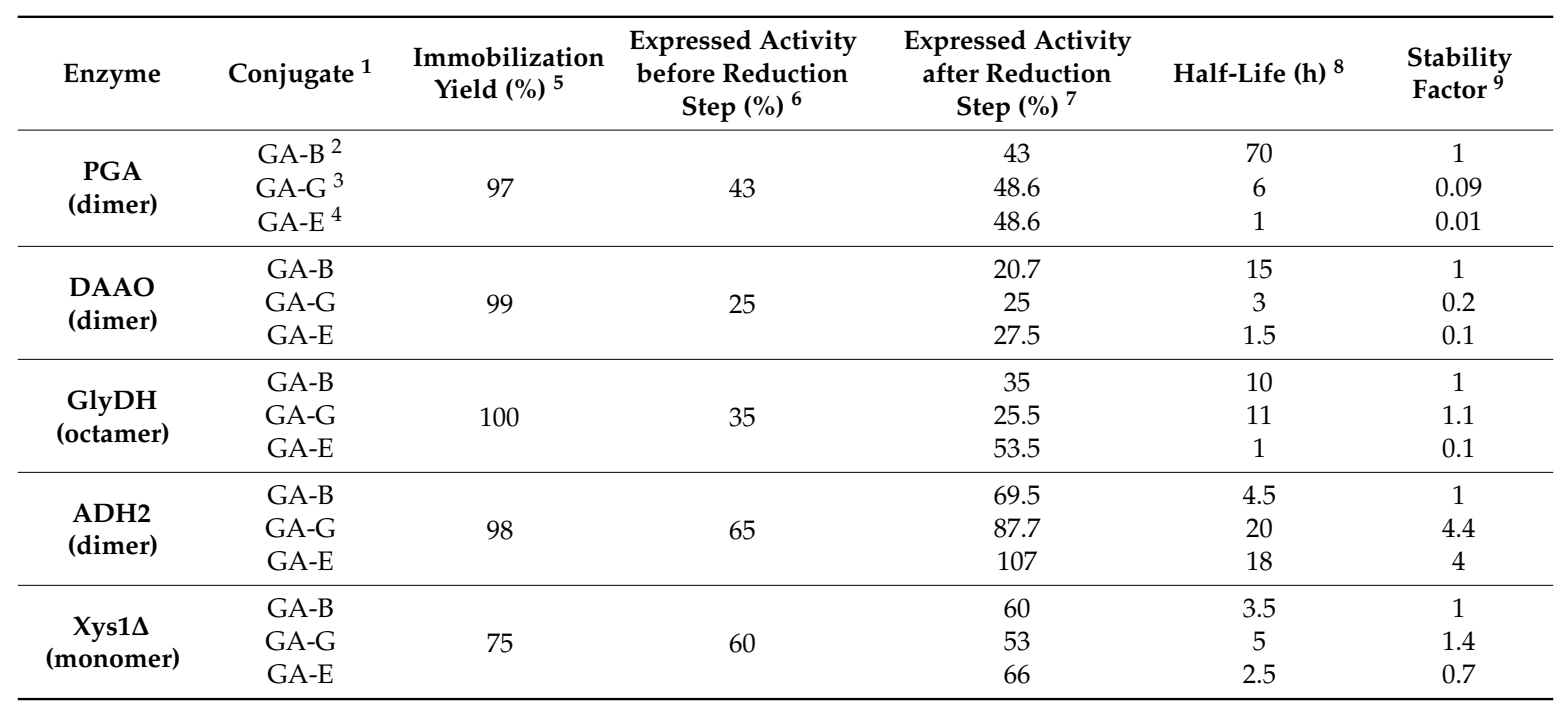

The conjugates were prepared as described in the Materials and Methods section. ${ }^{1}$ PGA and Xys1 $\Delta$ were immobilized on GA 10BCL; DAAO, GlyDH, and ADH2 were immobilized on GA 6BCL. ${ }^{2}$ GA-B, glyoxyl agarose conjugate that has been reduced with sodium borohydride. ${ }^{3} \mathrm{GA}-\mathrm{G}$, glyoxyl agarose conjugate that was reduced and blocked in the presence of 2-PB and glycine. ${ }^{4} \mathrm{GA}-\mathrm{E}$, glyoxyl agarose conjugate that has been reduced and blocked in the presence of 2-PB and ethanolamine. ${ }^{5}$ Immobilization yield (\%) = (activity of the solution offered for immobilization - activity in the supernatant at the end of the immobilization process)/(activity of the solution offered for immobilization) $\times 100 .{ }^{6}$ Expressed activity before the reduction step $(\%)=($ activity in the immobilized preparation before reduction)/(activity of the solution offered for immobilization - activity in the supernatant at the end of the immobilization process) $\times 100 .{ }^{7}$ Expressed activity after the reduction step $(\%)=($ activity in the immobilized preparation after reduction)/(activity of the solution offered for immobilization - activity in the supernatant at the end of the immobilization process) $\times 100 .{ }^{8}$ Half-life were calculated according to the Methods section. ${ }^{9}$ Stability factor is the ratio between the half-life, taking as reference the conjugates that were reduced with sodium borohydride. All the data are the mean values of three separate experiments where the error value was never higher to $5 \%$.

\subsection{Evaluation of the Correlation between Thermal Stability and Number of Enzyme-Support}

LinkageEnzyme immobilization on glyoxyl-activated supports is based on the reaction of aldehyde groups in the support, with $\varepsilon$-amino groups of the lysine residues on the enzyme surface. As a result, very stable secondary amino bonds were formed after the reduction step. Moreover, the increase in the thermal stability of the immobilized biocatalyst was previously correlated with an increasing number of lysine residues that were involved in multipoint covalent attachment [47].

To study whether the differences in thermostabilities were due to the decrease in the number of covalent support-enzyme bonds, the number of lysine residues that were involved in the immobilization process were quantified for the GA-B and the GA-G of PGA, DAAO, and Xys1 1 . It is important to note that the incubation time of the enzyme and the support at $\mathrm{pH} 10$ was the same for all conjugates. In this way, the differences obtained regarding thermal stabilities were unexpected, because theoretically, the number of bonds between the enzyme and support should be the same. In fact, as shown in Table 2, the number of immobilized lysine residues was similar for both procedures in three different enzymes studied. This result demonstrated that the differences found in the thermal stability for both methodologies do not rely on the number of covalent bonds between the enzyme and the support. 
Table 2. Quantification of lysine residues attached to the support.

\begin{tabular}{ccc}
\hline Enzyme & GA-B $^{\mathbf{1}}$ & GA-G $^{\mathbf{2}}$ \\
\hline PGA & 7 & 9 \\
DAAO & 4 & 5 \\
Xys1 $\Delta$ & 5 & 4 \\
\hline
\end{tabular}

${ }^{1}$ GA-B, glyoxyl agarose conjugate reduced with sodium borohydride. ${ }^{2}$ GA-G, glyoxyl agarose conjugate reduced and blocked in the presence of 2-PB and glycine. All the data are the mean value of three separated experiments where the error value was never higher to $5 \%$.

In light of these results, a possible explanation could be due to the blocking agents themselves, which could create chemical microenvironments on the support surface (Figure 4). The reduction step with borohydride led to a support surface that was full of hydroxyl groups, which were completely inert. The glycine procedure led to the secondary amino and carboxyl groups on the support surface, and the ethanolamine procedure led to secondary amino and hydroxyl groups. These three methodologies offer different chemical microenvironments on the support surface, and they could interact with the protein surface that was attached to the support in different ways, given the size of the blocking agent or the presence or the absence of charges. For example, the effects of the blocking step with glycine could be negative (PGA and DAAO), neutral (GlyDH) or positive (ADH2 and Xys1 $\Delta$ ) regarding thermal stability. Therefore, this alternative methodology could lead to a more stable biocatalyst than the conventional methodology in some cases depending on the enzyme. Accordingly, it opens the possibility to create another chemical microenvironment by using different amino acids as blocking agents.

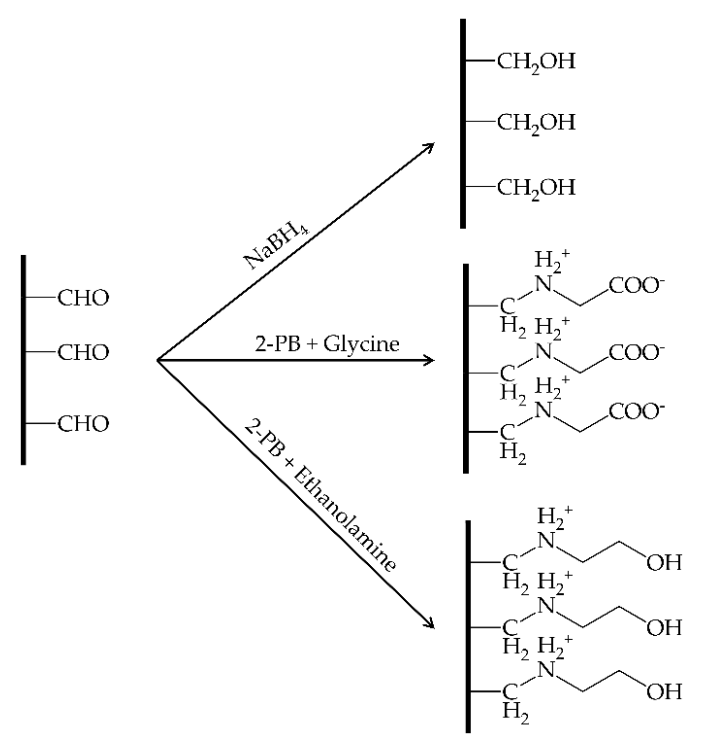

Figure 4. Scheme of the surface of the glyoxyl agarose support after three different reduction steps.

\subsection{Immobilization-Stabilization of a Bacterial Mandelate Dehydrogenase: Optimization of the Eduction Step}

The immobilization of a commercial ManDH on GA 6BCL was performed using the conventional and alternative reduction step. ManDH is an interesting enzyme for the asymmetric synthesis of chiral compounds from prochiral ones. ManDH was immobilized for $1 \mathrm{~h}$ at $25^{\circ} \mathrm{C}$ and reduced with sodium borohydride, resulting in a dramatic loss of the enzymatic activity (Table 3 ). The inactivation of the oxidoreductases during the immobilization process caused by alkaline conditions, and/or the reduction step has been previously described [11,29]. Thus, ManDH was immobilized under the same immobilization conditions, but with reduction of the conjugate with 2-PB in the presence of ethanolamine or glycine. Both preparations conserved all of the expressed activity after the reduction 
step, resulting in conjugates that were between 9.3- and 11-fold more active than the conjugate was reduced with borohydride.

In the same way, their thermal stabilities were assayed at $50{ }^{\circ} \mathrm{C}$ and $\mathrm{pH} 7$, using the soluble enzyme as a control (Table 3 and Figure S2). The low catalytic activity of the conjugate ManDH-GA-B did not allow us to test its thermal stability. The use of glycine as a blocking agent led to a more stable biocatalyst than the one blocked with ethanolamine. In addition, to optimize the immobilization protocol for ManDH on GA, three different biocatalysts were prepared: ManDH-GA-G1 (1 h at pH 10 and $\left.25{ }^{\circ} \mathrm{C}\right)$, ManDH-GA-G2 $\left(1 \mathrm{~h}\right.$ at $\mathrm{pH}$ and $\left.4{ }^{\circ} \mathrm{C}\right)$ and ManDH-GA-G3 (3 h at pH 10 and $4{ }^{\circ} \mathrm{C}$ ), with the aim to recover the maximum possible catalytic activity. Conjugates ManDH-GA-G2 and ManDH-GA-G3 showed higher expressed activity before reduction. However, both preparations lost between $30 \%$ and $50 \%$ of their activity after reduction with 2-PB in the presence of glycine. Nevertheless, ManDH-GA-G2 and ManDH-GA-G3 preparations were between 10- and 13-fold more active than ManDH-GA-B. With regard to the thermal stability of these ManDH conjugates, ManDH-GA-G1 was 5- and 3-fold more stable than ManDH-GA-G2 and G3, respectively (Table 3 and Figure S2).

Despite the loss of enzymatic activity, the preparation ManDH-GA-G1 achieved a half-life of $221 \mathrm{~h}$ at $50{ }^{\circ} \mathrm{C}$ and $\mathrm{pH} 7$ (Table 3 and Figure S2). The loss of activity during the immobilization process is partly offset by its increased thermal stability. Thus, the optimal conjugate was 357 -fold more stable than the soluble enzyme (half-life of $0.62 \mathrm{~h}$ ). This result was obtained due to the alternative reduction step with 2-PB in the presence of glycine. Therefore, this immobilization protocol allowed for the recovery of all the expressed activity of an enzyme that almost completely lost the catalytic activity following the conventional procedure of immobilization.

Table 3. Immobilization parameters of (R)-mandelate dehydrogenase (ManDH)-GA preparations.

\begin{tabular}{|c|c|c|c|c|c|}
\hline Conjugate & ManDH-GA-B ${ }^{1}$ & ManDH-GA-E ${ }^{2}$ & ManDH-GA-G1 ${ }^{3}$ & ManDH-GA-G2 ${ }^{4}$ & ManDH-GA-G3 ${ }^{5}$ \\
\hline Immobilization yield (\%) 6 & 99 & 99 & 99 & 99 & 99 \\
\hline $\begin{array}{l}\text { Expressed activity before } \\
\text { reduction step (\%) }\end{array}$ & 15 & 14 & 17 & 50 & 39 \\
\hline $\begin{array}{l}\text { Recovered activity after } \\
\text { reduction step }(\%)^{8}\end{array}$ & 1.5 & 14 & 16.5 & 16 & 19.5 \\
\hline Half-life $(\mathrm{h})^{9}$ & N.D. & 19 & 221 & 43 & 82 \\
\hline
\end{tabular}

${ }^{1}$ ManDH-GA-B and ManDH, immobilized on glyoxyl agarose and reduced with $\mathrm{NaBH}_{4} \cdot{ }^{2} \mathrm{ManDH}-\mathrm{GA}-\mathrm{E}$ and $\mathrm{ManDH}$, immobilized on glyoxyl agarose and reduced and blocked in the presence of 2-PB and ethanolamine. ${ }^{3}$ ManDH-GA-G1 and ManDH, immobilized on glyoxyl agarose for $1 \mathrm{~h}$ and $25^{\circ} \mathrm{C}$, and reduced and blocked in the presence of 2-PB and glycine. ${ }^{4} \mathrm{GA}-\mathrm{G} 2$, and $\mathrm{ManDH}$ were immobilized on glyoxyl agarose for $1 \mathrm{~h}$ and $4{ }^{\circ} \mathrm{C}$, and reduced and blocked in the presence of 2-PB and glycine. ${ }^{5}$ GA-G3 and ManDH, immobilized on glyoxyl agarose for $3 \mathrm{~h}$ and $4{ }^{\circ} \mathrm{C}$, and reduced and blocked in the presence of 2-PB and glycine. ${ }^{6}$ Immobilization yield $(\%)=$ (activity of the solution offered for immobilization - activity in the supernatant at the end of the immobilization process)/(activity of the solution offered for immobilization) $\times 100 .{ }^{7}$ Expressed activity $(\%)=$ (activity in the immobilized preparation)/(activity of the solution offered for immobilization - activity in the supernatant at the end of the immobilization process $) \times 100 .{ }^{8}$ Expressed activity after reduction step $(\%)=($ activity in the immobilized preparation after reduction)/(activity of the solution offered for immobilization - activity in the supernatant at the end of the immobilization process) $\times 100 .{ }^{9}$ Half-life times were calculated according to the Methods section. ${ }^{10}$ The stability factor is the ratio between the half-life, taking as the reference the soluble enzyme $\left(0.62 \mathrm{~h}\right.$ at $50^{\circ} \mathrm{C}$ and $\mathrm{pH}$ 7). All the data are the mean value of three separated experiments where the error value was never higher to $5 \%$.

\section{Materials and Methods}

\subsection{Materials}

Penicillin G acylase (PGA) from E. coli was kindly provided by Antibioticos S.A. (León, Spain). D-amino acid oxidase (DAAO) from T. variabilis was kindly provided by Recordati SRL (Milan, Italy). The bacterial $(R)$-mandelate dehydrogenase $(\mathrm{ManDH})$ was purchased from Applichem (Darmstadt, Germany). Glycerol dehydrogenase (GlyDH) from Celullomonas sp., horseradish peroxidase (HRP) and dimethyl sulfoxide (DMSO) were purchased from Sigma-Aldrich (St. Louis, IL, USA). Expression plasmid containing the Xys1 $\Delta$ encoding sequence of $S$. halstedii was kindly donated by Prof. Ramón 
I. Santamaría (Instituto de Biología Functional y Genómica, CSIC, Salamanca, Spain). Prof. José Berenguer (Centro de Biología Molecular Severo Ochoa, CSIC-UAM, Madrid, Spain) kindly donated the expression plasmid containing the ADH2 encoding sequence of T. thermophilus HB27. Agarose beads $6 \%$ and $10 \%$ cross-linked (BCL) were obtained from Agarose Beads Technology (Madrid, Spain). 2-Picoline borane (2-PB) complex was purchased from TCI (Tokyo, Japan). Dimethyl sulfoxide (DMSO) was purchased from Applichem (Darmstadt, Germany). 6-nitro-3-phenylacetamidobenzoic acid (NIPAB) was purchased from Fluorochem (Hadfield, United Kingdom). Beechwood xylan was purchased from Megazyme (Wicklow, Ireland). Glycine, ethanolamine, glycidol, o-phenylenediamine (OPD), 2,2,2-trifluoroacetophenone, phenylalanine, glycerol, $\beta$-nicotinamide adenine dinucleotide reduced (NADH) and the oxidized form $\left(\mathrm{NAD}^{+}\right)$, phenylglyoxylate and dinitrosalicylic acid (DNS) were purchased from Sigma-Aldrich Co. (St. Louis, IL, USA). Buffers and other reagents were obtained from Sigma-Aldrich Co. (St. Louis, IL, USA).

\subsection{Methods}

\subsubsection{Protein Production}

Xys1 $\Delta$ [37] and ADH2 [29] enzymes were expressed and purified according to the literature.

\subsubsection{Enzymatic Assays}

PGA, DAAO, ADH2, GlyDH, and ManDH enzymatic activities were measured spectrophotometrically using NIPAB, D-phenylalanine, 2,2,2-trifluoroacetophonene, glycerol, and phenylglyoxylate as substrates respectively according to the literature $[11,29,48,49]$. Table 4 shows a brief description of the enzymatic assays used in this work. All enzymatic assays were carried out on a V-730 spectrophotometer from JASCO Analitica Spain S.L. (Madrid, Spain).

Table 4. Summary of continuous enzymatic assays.

\begin{tabular}{|c|c|c|c|c|}
\hline Enzyme & Buffer & Substrate $^{1}$ & Temperature $\left({ }^{\circ} \mathrm{C}\right)^{2}$ & Wavelength (nm) \\
\hline PGA & $\begin{array}{l}50 \mathrm{mM} \text { sodium } \\
\text { phosphate } \mathrm{pH} 7\end{array}$ & $0.15 \mathrm{mM}$ NIPAB & 25 & 405 \\
\hline $\mathrm{DAAO}^{3}$ & $\begin{array}{l}50 \mathrm{mM} \text { sodium } \\
\text { phosphate pH } 7.5\end{array}$ & $\begin{array}{c}10 \mathrm{mM} \\
\text { D-phenylalanine }\end{array}$ & 25 & 450 \\
\hline $\mathrm{ADH} 2$ & $\begin{array}{l}50 \mathrm{mM} \text { sodium } \\
\text { phosphate } \mathrm{pH} 7\end{array}$ & $\begin{array}{c}10 \mathrm{mM} \\
\text { 2,2,2-trifluoroacetophenone } \\
\text { and } 0.25 \mathrm{mM} \text { NADH }\end{array}$ & e & 340 \\
\hline GlyDH & $\begin{array}{l}50 \mathrm{mM} \text { sodium } \\
\text { phosphate } \mathrm{pH} 7\end{array}$ & $\begin{array}{c}100 \mathrm{mM} \text { glycerol and } \\
2.5 \mathrm{mM} \mathrm{NAD}^{+}\end{array}$ & 25 & 340 \\
\hline ManDH & $\begin{array}{l}0.1 \mathrm{M} \text { potassium } \\
\text { phosphate } \mathrm{pH} 7\end{array}$ & $\begin{array}{c}1.5 \mathrm{mM} \\
\text { phenylglyoxylate and } \\
0.25 \mathrm{mM} \mathrm{NADH}\end{array}$ & 30 & 340 \\
\hline
\end{tabular}

${ }^{1}$ The final substrate concentrations in the cuvette are indicated in each case. ${ }^{2}$ All substrates were pre-incubated at the given temperature before the enzymatic assays. ${ }^{3}$ The DAAO enzymatic assay also contains in the cuvette 0.1 $\mathrm{mg} / \mathrm{mL}$ of $\mathrm{HRP}$ and $0.1 \mathrm{mg} / \mathrm{mL}$ of OPD.

Xylanase activity was colorimetrically measured by the dinitrosalycilic acid (DNS) method, using xylose as standard [50]. A mixture of $4 \%(w / v)$ beechwood xylan in $50 \mathrm{mM}$ sodium acetate buffer at pH 5.0 was stirred for $1 \mathrm{~h}$ at $25^{\circ} \mathrm{C}$ and then centrifuged for $1 \mathrm{~h}$ at $3750 \mathrm{rpm}$. The soluble fraction was diluted to $1 \%(w / v)$ for the xylanase activity assay. The conditions for xylanase activity assay were $10 \mathrm{~min}$ at $25^{\circ} \mathrm{C}$ under constant agitation in $50 \mathrm{mM}$ sodium acetate buffer $\mathrm{pH}$ 5.0, containing $100 \mu \mathrm{L}$ of xylanase solution and $900 \mu \mathrm{L}$ of $1 \%$ xylan substrate. One unit of enzyme activity was defined as the amount of enzyme required to release $1 \mu \mathrm{mol}$ of reducing sugars (xylose equivalents) in $1 \mathrm{~min}$. 


\subsubsection{Support Immobilization Preparation}

GA support was prepared by esterification of agarose 6BCL 100 ( $\mu$ moles of aldehyde groups $/ \mathrm{mL}$ of support) or 10BCL ( $200 \mu$ moles of aldehyde groups $/ \mathrm{mL}$ of support) with glycidol, and the further oxidation of the resulting glyceryl agarose with the appropriate amount of periodate, as previously described [18]. Aldehyde groups were quantified by the $\mathrm{NaIO}_{4}$ consumption method [18].

\subsubsection{Protein Immobilization}

PGA, DAAO, ADH2, Xys1 $\triangle$, and GlyDH were immobilized on a GA support, as previously described, but with some changes [11,29,37-39]. Table 2 summarizes the protein immobilization conditions that were used in this study for each enzyme. All protein immobilization procedures were carried out under gentle stirring, at $\mathrm{pH} 10$, and $4{ }^{\circ} \mathrm{C}$ or $25^{\circ} \mathrm{C}$.

Different conjugates of the commercial ManDH were prepared by varying the immobilization time $(1$ or $3 \mathrm{~h})$, and the immobilization temperature $\left(4^{\circ} \mathrm{C}\right.$ or $\left.25^{\circ} \mathrm{C}\right)$.

In all the preparations, $1 \mathrm{~g}$ of support was added to $10 \mathrm{~mL}$ of immobilization buffer containing the indicated amount of enzyme (Table 5).

Table 5. Protein immobilization conditions summary.

\begin{tabular}{|c|c|c|c|c|}
\hline Enzyme & $\begin{array}{l}\text { Immobilization } \\
\text { Time (h) }\end{array}$ & Immobilization Buffer & $\begin{array}{l}\text { Offered Protein per g } \\
\text { of Support (mg) }\end{array}$ & Temperature $\left({ }^{\circ} \mathrm{C}\right)$ \\
\hline PGA & 1 & $\begin{array}{l}0.1 \mathrm{M} \text { sodium bicarbonate } \\
\mathrm{pH} 10,0.1 \mathrm{M} \text { phenylacetic } \\
\text { and } 25 \% \text { glycerol }\end{array}$ & 5 & 25 \\
\hline DAAO & 1 & $\begin{array}{l}0.1 \mathrm{M} \text { sodium bicarbonate } \\
\text { buffer } \mathrm{pH} 10\end{array}$ & 2.7 & 25 \\
\hline $\mathrm{ADH} 2$ & 6 & $\begin{array}{l}0.1 \mathrm{M} \text { sodium bicarbonate } \\
\text { buffer } \mathrm{pH} 10\end{array}$ & 2 & 25 \\
\hline GlyDH & 3 & $\begin{array}{l}0.1 \mathrm{M} \text { sodium bicarbonate } \\
\text { buffer } \mathrm{pH} 10\end{array}$ & 2.5 & 25 \\
\hline Xys1 $\Delta$ & 24 & $\begin{array}{l}0.1 \mathrm{M} \text { sodium bicarbonate } \\
\text { buffer } \mathrm{pH} 10\end{array}$ & 10 & 4 \\
\hline $\mathrm{ManDH}$ & $1-3$ & $\begin{array}{l}0.1 \mathrm{M} \text { potassium } \\
\text { bicarbonate buffer } \mathrm{pH} 10 \\
\text { and } 40 \% \text { trehalose }\end{array}$ & 0.5 & $4-25$ \\
\hline
\end{tabular}

All enzymes were immobilized at $25^{\circ} \mathrm{C}$, excepting the Xys1 $\Delta$ that was immobilized at $4{ }^{\circ} \mathrm{C}$.

To finish the protein immobilization process, all immobilized preparations were reduced with 2-PB or sodium borohydride, as indicated below.

Reduction of Schiff Base with Sodium Borohydride

The immobilization process was finalized by the addition of $10 \mathrm{mg}$ of solid $\mathrm{NaBH}_{4}$ to the suspension. The mixture was kept for 30 minutes under gentle stirring at $25^{\circ} \mathrm{C}$. Finally, each conjugate was washed with $25 \mathrm{mM}$ sodium phosphate buffer $\mathrm{pH} 7$ to remove the excess of $\mathrm{NaBH}_{4}$. In this way, all Schiff bases formed between the amino groups of the enzyme and the aldehyde groups of the support were transformed into secondary amino bonds. In addition, the remaining glyoxyl groups are converted into inert hydroxyl groups (Figure 1).

Reduction of Schiff Bases with the 2-Picoline Borane Complex

One gram of the conjugate was filtered and resuspended (without washing) in a volume of $15 \mathrm{~mL}$ containing $0.8 \mathrm{M}$ ethanolamine, glycine or 2-amino-2-(hydroxymethyl)-1,3-propanediol hydrochloride (Tris- $\mathrm{HCl}) \mathrm{pH} 9,20 \%$ of dimethyl sulfoxide (DMSO) $(v / v)$, and $40 \mathrm{mM}$ of 2-PB. Ethanolamine, glycine, and Tris- $\mathrm{HCl}$ were assayed as blocking agents of the remaining aldehyde groups of the support after 
the immobilization process. The conjugate was incubated under these conditions for $24 \mathrm{~h}$ under gentle stirring at $25{ }^{\circ} \mathrm{C}$. Finally, each conjugate was washed with an excess of $25 \mathrm{mM}$ sodium phosphate buffer at $\mathrm{pH}$ 7. The presence or absence of aldehydes groups was qualitatively measured by using Schiff's reagent.

\subsubsection{Thermal Inactivation Assays}

Thermal stability assays of different conjugates were performed at $\mathrm{pH} 7$ and $50{ }^{\circ} \mathrm{C}$ (for ManDH), $60{ }^{\circ} \mathrm{C}$ (for DAAO and PGA), $65^{\circ} \mathrm{C}$ (for Xys1 $\Delta$ and GlyDH), or $80^{\circ} \mathrm{C}$ (for ADH2). Samples were periodically withdrawn, and their activities were assayed. Half-lives and stabilization factors were calculated as previously described [51].

3.2.6. Estimation of the Lysine Residues Involved in the Immobilization of the Enzyme on the GA Support

The number of lysine residues of DAAO, PGA, and Xys1 $\Delta$ involved in the covalent attachment to the support was calculated according to the literature [47]. First, the amino acid composition was measured for each soluble enzymes and conjugates. Then, the number of lysine residues involved in the immobilization process $(\mathrm{K})$ was calculated from the formula:

$$
\mathrm{K}=\frac{\% \text { lysine in conjugate } \times \text { number of lysine residues of enzymatic molecule }}{\% \text { lysine in soluble enzymes }}
$$

\section{Conclusions}

In this study, we presented 2-PB as an alternative to borohydride for the end-point enzyme immobilization process on aldehyde-activated supports. Borohydride is able to reduce the remaining aldehyde groups on the support to inert and hydrophilic hydroxyl ones. 2-PB, a milder reducing agent, is not able to reduce aldehyde groups. Thus, the reduction of the Schiff base that is formed between the aldehyde groups from the support and amino groups from the enzymes with 2-PB requires a small amino compound capable of blocking the non-reacted aldehyde groups on the support surface. On the one hand, the intensity of the reduction of the Schiff bases by 2-PB was proven to be similar to the ones obtained with borohydride. In addition, the deleterious effects on enzyme activity were much lower for some enzymes. For example, immobilized ManDH on GA only retained 1.5\% of its initial activity after borohydride reduction, but the optimal conjugate that was reduced with 2-PB was 13-fold more active. Thus, 2-PB is highly recommended for enzymes that are very sensitive to borohydride reduction. On the other hand, the blocking of the support with different amino compounds can create different microenvironments on the support surface with different stabilizing effects. In some cases, this microenvironment may have additional positive effects on the stability of immobilized biocatalysts. For example, immobilized ADH2 on GA was 4.4-fold more stable at $80^{\circ} \mathrm{C}$ and $\mathrm{pH} 7$ when blocked with glycine in the presence of 2-PB than when directly reduced with borohydride. Moreover, immobilized ManDH on GA was 11.6-fold more stable when blocked with glycine than when blocked with ethanolamine, and 357 -fold more stable than a soluble enzyme at $50{ }^{\circ} \mathrm{C}$ and $\mathrm{pH} 7$. Therefore, this alternative methodology could lead to a more stable and active biocatalyst than the conventional methodology, depending on the enzyme.

Supplementary Materials: The following are available online at http:/ /www.mdpi.com/2073-4344/8/8/333/s1, Figure S1: Thermal stabilities of immobilized preparations of Xys1 $\Delta$, PGA, DAOO, GlyDH, and ADH2, Figure S2: Thermal inactivation course at $50{ }^{\circ} \mathrm{C}$ and $\mathrm{pH} 7$ of immobilized $\mathrm{ManDH}$ preparations. 
Author Contributions: Conceptualization, J.M.G. and J.R.-M.; Methodology, J.M.G., J.R.-M. and A.H.O.; Validation, J.R.-M., M.R.-F., M.d.M.Y. and A.H.O.; Formal Analysis, J.R.-M., A.H.O., M.d.C.M.-L. and M.R.-F.; Investigation, A.H.O., M.R.-F., M.d.M.Y. and M.d.C.M.-L.; Resources, J.R.-M. and J.M.G.; Data Curation, A.H.O., J.R.-M. and M.d.M.Y.; Writing-Original Draft Preparation, J.R.-M., A.H.O. and M.R.-F.; Writing-Review \& Editing, J.R.-M. and J.M.G.; Visualization, J.M.G., M.d.M.Y. and J.R.-M.; Supervision, J.M.G. and J.R.-M.; Project Administration, J.M.G.; Funding Acquisition, J.M.G.

Funding: This research was funded by the Spanish Ministry of Economy, Industry and Competitiveness (projects BIO2012-36861 and CTQ2015-70348) and the EU FP7 project SuSy (Sucrose Synthase as Cost-Effective Mediator of Glycosylation Reactions, C-KBBE/3293). Javier Rocha-Martin is grateful for the Juan de la Cierva fellowship (IJCI-2014-19260) funded by the Spanish Ministry of Economy, Industry and Competitiveness. The authors would like to thank the Spanish Ministry of Economy, Industry and Competitiveness for financial support awarded María Fernández-Romero (BES-2013-065396).

Acknowledgments: The enzyme production was carried out in the 'CBMSO Fermentation Facility'.

Conflicts of Interest: The authors declare no conflict of interest. The founding sponsors had no role in the design of the study; in the collection, analyses, or the interpretation of data; in the writing of the manuscript, and in the decision to publish the results.

\section{References}

1. Paradisi, F. Biocatalysis takes to flow. Chim. Oggi/Chem. Today 2017, 35, 38-40.

2. Choi, J.M.; Han, S.S.; Kim, H.S. Industrial applications of enzyme biocatalysis: Current status and future aspects. Biotechnol. Adv. 2015, 33, 1443-1454. [CrossRef] [PubMed]

3. DiCosimo, R.; McAuliffe, J.; Poulose, A.J.; Bohlmann, G. Industrial use of immobilized enzymes. Chem. Soc. Rev. 2013, 42, 6437-6474. [PubMed]

4. Wells, A.; Meyer, H.P. Biocatalysis as a strategic green technology for the chemical industry. ChemCatChem 2014, 6, 918-920. [CrossRef]

5. Valavanidis, A. Biocatalysis and directed evolution in the pharmaceutical industry. New developments for 'green' synthetic methods of high value pharmaceuticals. Pharmakeftiki 2016, 28, 117-130.

6. Homaei, A.A.; Sariri, R.; Vianello, F.; Stevanato, R. Enzyme immobilization: An update. J. Chem. Biol. 2013, 6, 185-205. [CrossRef] [PubMed]

7. Brady, D.; Jordaan, J. Advances in enzyme immobilisation. Biotechnol. Lett 2009, 31, 1639-1650. [CrossRef] [PubMed]

8. Mateo, C.; Palomo, J.M.; Fernandez-Lorente, G.; Guisan, J.M.; Fernandez-Lafuente, R. Improvement of enzyme activity, stability and selectivity via immobilization techniques. Enzym. Microb. Technol. 2007, 40, 1451-1463. [CrossRef]

9. Fernández-Lorente, G.; Lopez-Gallego, F.; Bolivar, J.M.; Rocha-Martin, J.; Moreno-Perez, S.; Guisán, J.M. Immobilization of proteins on highly activated glyoxyl supports: Dramatic increase of the enzyme stability via multipoint immobilization on pre-existing carriers. Curr. Org. Chem. 2015, 19, 1-13. [CrossRef]

10. Fernández-Lorente, G.; Betancor, L.; Carrascosa, A.V.; Palomo, J.M.; Guisan, J.M. Modulation of the selectivity of immobilized lipases by chemical and physical modifications: Release of omega-3 fatty acids from fish oil. J. Am. Oil Chem. Soc. 2012, 89, 97-102. [CrossRef]

11. Rocha-Martin, J.; Acosta, A.; Berenguer, J.; Guisan, J.M.; Lopez-Gallego, F. Selective oxidation of glycerol to 1,3-dihydroxyacetone by covalently immobilized glycerol dehydrogenases with higher stability and lower product inhibition. Bioresour. Technol. 2014, 170, 445-453. [CrossRef] [PubMed]

12. Liese, A.; Hilterhaus, L. Evaluation of immobilized enzymes for industrial applications. Chem. Soc. Rev. 2013, 42, 6236-6249. [CrossRef] [PubMed]

13. Eş, I.; Vieira, J.D.G.; Amaral, A.C. Principles, techniques, and applications of biocatalyst immobilization for industrial application. Appl. Microbiol. Biotechnol. 2015, 99, 2065-2082. [CrossRef] [PubMed]

14. Brena, B.; González-Pombo, P.; Batista-Viera, F. Immobilization of Enzymes: A Literature Survey. In Immobilization of Enzymes and Cells: Third Edition; Guisan, J.M., Ed.; Humana Press: Totowa, NJ, USA; New York, NY, USA, 2013; pp. 15-31.

15. Datta, S.; Christena, L.R.; Rajaram, Y.R.S. Enzyme immobilization: An overview on techniques and support materials. 3 Biotech. 2013, 3, 1-9. [PubMed]

16. Garcia-Galan, C.; Berenguer-Murcia, Á.; Fernandez-Lafuente, R.; Rodrigues, R.C. Potential of different enzyme immobilization strategies to improve enzyme performance. Adv. Synth. Catal. 2011, 353, $2885-2904$. 
17. Bernal, C.; Guzman, F.; Illanes, A.; Wilson, L. Selective and eco-friendly synthesis of lipoaminoacid-based surfactants for food, using immobilized lipase and protease biocatalysts. Food Chem. 2018, 239, $189-195$. [CrossRef] [PubMed]

18. Guisán, J.M. Aldehyde-agarose gels as activated supports for immobilization-stabilization of enzymes. Enzym. Microb. Technol. 1988, 10, 375-382. [CrossRef]

19. Benítez-Mateos, A.I.; Sebastian, E.S.; Ríos-Lombardía, N.; Morís, F.; González-Sabín, J.; López-Gallego, F. asymmetric reduction of prochiral ketones by using self-sufficient heterogeneous biocatalysts based on NADPH-dependent ketoreductases. Chem. Eur. J. 2017, 23, 16843-16852. [CrossRef] [PubMed]

20. Romero-Fernández, M.; Moreno-Perez, S.; Orrego, A.H.; Martins de Oliveira, S.; Santamaría, R.I.; Díaz, M.; Guisan, J.M.; Rocha-Martin, J. Designing continuous flow reaction of xylan hydrolysis for xylooligosaccharides production in packed-bed reactors using xylanase immobilized on methacrylic polymer-based supports. Bioresour. Technol. 2018, 266, 249-258. [CrossRef] [PubMed]

21. Marques Netto, C.G.C.; da Silva, D.G.; Toma, S.H.; Andrade, L.H.; Nakamura, M.; Araki, K.; Toma, H.E. Bovine glutamate dehydrogenase immobilization on magnetic nanoparticles: Conformational changes and catalysis. RSC Adv. 2016, 6, 12977-12992. [CrossRef]

22. Bassan, J.; de Souza Bezerra, T.; Peixoto, G.; da Cruz, C.; Galán, J.; Vaz, A.; Garrido, S.; Filice, M.; Monti, R. Immobilization of trypsin in lignocellulosic waste material to produce peptides with bioactive potential from whey protein. Materials 2016, 9, 357. [CrossRef] [PubMed]

23. Bezerra, T.M.d.S.; Bassan, J.C.; Santos, V.T.d.O.; Ferraz, A.; Monti, R. Covalent immobilization of laccase in green coconut fiber and use in clarification of apple juice. Process. Biochem. 2015, 50, 417-423. [CrossRef]

24. Mateo, C.; Bolivar, J.M.; Godoy, C.A.; Rocha-Martin, J.; Pessela, B.C.; Curiel, J.A.; Muñoz, R.; Guisan, J.M.; Fernández-Lorente, G. Improvement of enzyme properties with a two-step immobilizaton process on novel heterofunctional supports. Biomacromolecules 2010, 11, 3112-3117. [CrossRef] [PubMed]

25. Orrego, A.H.; Garcia, C.; Mancheno, J.M.; Guisan, J.M.; Lillo, M.P.; Lopez-Gallego, F. Two-Photon Fluorescence Anisotropy Imaging to Elucidate the Dynamics and the Stability of Immobilized Proteins. J. Phys. Chem. B 2016, 120, 485-491. [CrossRef] [PubMed]

26. Ottone, C.; Bernal, C.; Serna, N.; Illanes, A.; Wilson, L. Enhanced long-chain fatty alcohol oxidation by immobilization of alcohol dehydrogenase from S. cerevisiae. Appl. Microbiol. Biotechnol. 2018, 102, $237-247$. [CrossRef] [PubMed]

27. de Oliveira, S.M.; Moreno-Perez, S.; Terrasan, C.R.F.; Romero-Fernández, M.; Vieira, M.F.; Guisan, J.M.; Rocha-Martin, J. Covalent immobilization-stabilization of $\beta-1,4$-endoxylanases from Trichoderma reesei: Production of xylooligosaccharides. Process. Biochem. 2018, 64, 170-176. [CrossRef]

28. Trobo-Maseda, L.; Orrego, A.H.; Moreno-Pérez, S.; Fernández-Lorente, G.; Guisan, J.M.; Rocha-Martin, J. Stabilization of multimeric sucrose synthase from Acidithiobacillus caldus via immobilization and post-immobilization techniques for synthesis of UDP-glucose. Appl. Microbiol. Biotechnol. 2018, 102, 773-787. [CrossRef] [PubMed]

29. Rocha-Martín, J.; Vega, D.; Bolivar, J.M.; Hidalgo, A.; Berenguer, J.; Guisán, J.M.; López-Gallego, F. Characterization and further stabilization of a new anti-prelog specific alcohol dehydrogenase from Thermus thermophilus HB27 for asymmetric reduction of carbonyl compounds. Bioresour. Technol. 2012, 103, 343-350. [CrossRef] [PubMed]

30. Orrego, A.H.; Trobo-Maseda, L.; Rocha-Martin, J.; Guisan, J.M. Immobilization-stabilization of a complex multimeric sucrose synthase from Nitrosomonas europaea. Synthesis of UDP-glucose. Enzym. Microb. Technol. 2017, 105, 51-58. [CrossRef] [PubMed]

31. Jackson, E.; López-Gallego, F.; Guisan, J.M.; Betancor, L. Enhanced stability of L-lactate dehydrogenase through immobilization engineering. Process. Biochem. 2016, 51, 1248-1255. [CrossRef]

32. López-Gallego, F.; Fernandez-Lorente, G.; Rocha-Martin, J.; Bolivar, J.M.; Mateo, C.; Guisan, J.M. Stabilization of enzymes by multipoint covalent immobilization on supports activated with glyoxyl groups. Methods Mol. Biol. 2013, 1051, 59-71. [PubMed]

33. Sato, S.; Sakamoto, T.; Miyazawa, E.; Kikugawa, Y. One-pot reductive amination of aldehydes and ketones with $\alpha$-picoline-borane in methanol, in water, and in neat conditions. Tetrahedron 2004, 60, 7899-7906. [CrossRef] 
34. Ruhaak, L.R.; Steenvoorden, E.; Koeleman, C.A.M.; Deelder, A.M.; Wuhrer, M. 2-Picoline-borane: A non-toxic reducing agent for oligosaccharide labeling by reductive amination. Proteomics 2010, 10, 2330-2336. [CrossRef] [PubMed]

35. Cosenza, V.A.; Navarro, D.A.; Stortz, C.A. Usage of $\alpha$-picoline borane for the reductive amination of carbohydrates. ARKIVOC 2011, 2011, 182-194.

36. Ambrogelly, A.; Cutler, C.; Paporello, B. Screening of reducing agents for the pegylation of recombinant human IL-10. Protein J. 2013, 32, 337-342. [CrossRef] [PubMed]

37. Aragon, C.C.; Mateo, C.; Ruiz-Matute, A.I.; Corzo, N.; Fernandez-Lorente, G.; Sevillano, L.; Díaz, M.; Monti, R.; Santamaría, R.I.; Guisan, J.M. Production of xylo-oligosaccharides by immobilized-stabilized derivatives of endo-xylanase from Streptomyces halstedii. Process. Biochem. 2013, 48, 478-483. [CrossRef]

38. Betancor, L.; Hidalgo, A.; Fernández-Lorente, G.; Mateo, C.; Rodríguez, V.; Fuentes, M.; López-Gallego, F.; Fernández-Lafuente, R.; Guisan, J.M. Use of physicochemical tools to determine the choice of optimal enzyme: Stabilization of D-amino acid oxidase. Biotechnol. Prog. 2003, 19, 784-788. [CrossRef] [PubMed]

39. Alvaro, G.; Fernandez-Lafuente, R.; Blanco, R.M.; Guisán, J.M. Immobilization-stabilization of Penicillin G acylase from Escherichia coli. Appl. Biochem. Biotechnol. 1990, 26, 181-195. [CrossRef] [PubMed]

40. Romero-Fernández, M.; Moreno-Perez, S.; Martins de Oliveira, S.; Santamaría, R.I.; Guisan, J.M.; Rocha-Martin, J. Preparation of a robust immobilized biocatalyst of $\beta-1,4$-endoxylanase by surface coating with polymers for production of xylooligosaccharides from different xylan sources. New Biotechnol. 2018, 44, 50-58. [CrossRef] [PubMed]

41. Basu, A.; Kunduru, K.R.; Katzhendler, J.; Domb, A.J. Poly( $\alpha$-hydroxy acid)s and poly( $\alpha$-hydroxy acid-co- $\alpha$-amino acid)s derived from amino acid. Adv. Drug Del. Rev. 2016, 107, 82-96. [CrossRef] [PubMed]

42. Kneedler, J.A.; Sky, S.S.; Sexton, L.R. Understanding alpha-hydroxy acids. Dermatol. Nurs./Dermatol. Nurses' Assoc. 1998, 10, 247-254, 259-262, quiz 265-266.

43. Howard, P.C.; Sams Ii, R.L.; Dennis, D.A.; Wamer, W.G. Alpha-hydroxy acids: Consideration of the biological effects and possible role in photocarcinogenesis. J. Food Drug Anal. 2002, 10, 258-261.

44. Kawase, Y.; Yamagishi, T.; Kutsuma, T.; Ueda, K.; Iwakuma, T.; Nakata, T.; Yokomatsu, T. One-pot synthesis of alkoxyamine derivatives by reductive alkoxyamination with a 2-picoline-borane complex. Heterocycles 2009, 78, 463-470. [CrossRef]

45. Tamashima, E.; Hayama, T.; Yoshida, H.; Imakyure, O.; Yamaguchi, M.; Nohta, H. Direct tandem mass spectrometric analysis of amino acids in plasma using fluorous derivatization and monolithic solid-phase purification. J. Pharm. Biomed. Anal. 2015, 115, 201-207. [CrossRef] [PubMed]

46. Duff, R.J.; Smith, E.; Li, W.; Fodor, S. Evidence for an imidazoline by-product from glycans using tandem mass spectrometry. J. Chromatogr. A 2017, 1501, 61-67. [CrossRef] [PubMed]

47. Pedroche, J.; del Mar Yust, M.; Mateo, C.; Fernández-Lafuente, R.; Girón-Calle, J.; Alaiz, M.; Vioque, J.; Guisán, J.M.; Millán, F. Effect of the support and experimental conditions in the intensity of the multipoint covalent attachment of proteins on glyoxyl-agarose supports: Correlation between enzyme-support linkages and thermal stability. Enzym. Microb. Technol. 2007, 40, 1160-1166. [CrossRef]

48. Grazú, V.; López-Gallego, F.; Montes, T.; Abian, O.; González, R.; Hermoso, J.A.; García, J.L.; Mateo, C.; Guisán, J.M. Promotion of multipoint covalent immobilization through different regions of genetically modified penicillin G acylase from E. coli. Process. Biochem. 2010, 45, 390-398. [CrossRef]

49. López-Gallego, F.; Betancor, L.; Hidalgo, A.; Alonso, N.; Fernandez-Lorente, G.; Guisan, J.M.; Fernandez-Lafuente, R. Preparation of a robust biocatalyst of d-amino acid oxidase on sepabeads supports using the glutaraldehyde crosslinking method. Enzym. Microb. Technol. 2005, 37, 750-756. [CrossRef]

50. Miller, G.L. Use of dinitrosalicylic acid reagent for determination of reducing sugar. Anal. Chem. 1959, 31, 426-428. [CrossRef]

51. Romero, O.; Guisán, J.M.; Illanes, A.; Wilson, L. Reactivation of penicillin acylase biocatalysts: Effect of the intensity of enzyme-support attachment and enzyme load. J. Mol. Catal. B: Enzym. 2012, 74, 224-229. [CrossRef]

(C) 2018 by the authors. Licensee MDPI, Basel, Switzerland. This article is an open access article distributed under the terms and conditions of the Creative Commons Attribution (CC BY) license (http://creativecommons.org/licenses/by/4.0/). 